\title{
TARIF BEA MASUK ATAS BARANG IMPOR BERDASARKAN UNDANG-UNDANG KEPABEANAN
}

\author{
Jatmiko Winarno ${ }^{1}$ \\ ${ }^{1)}$ Dosen Fakultas Hukum Universitas Islam Lamongan.
}

\begin{abstract}
ABSTRAK
Sistem kepabeanan di Indonesia menganut sistem self assessment, dimana importir diminta untuk memberitahukan di dalam pemberitahuan impor barang (PIB) berupa jumlah, jenis dan harga barang. Besar kecilnya pungutan negara sangat bergantung pula besarnya nilai pabean yang diberitahukan importir, sehingga pemberitahuan nilai pabean ini harus diteliti oleh Pejabat Bea dan Cukai. Tujuannya untuk menghindari pemberitahuan nilai pabean yang lebih rendah dari yang seharusnya, sehingga mengakibatkan kerugian penerimaan negara dari sektor bea masuk, cukai dan pajak dalam rangka impor. Penulis mengetengahkan 2 (dua) rumusan permasalahan. Pertama mengenai pengaturan bea masuk atas barang impor berdasarkan Undang-Undang Kepabeanan (UU. Nomor 17 Tahun 2006). Kedua mengenai akibat hukum dari pengaturan tarif bea masuk atas barang impor tersebut. Adapun tujuan penelitian ini adalah untuk mengetahui pengaturan dan akibat hukum dari tarif bea masuk atas barang impor berdasarkan Undang-Undang Kepabeanan. Pejabat Bea dan Cukai tetap diberi wewenang untuk meneliti dan menetapkan tarif dan nilai pabean untuk perhitungan bea masuk. Selain itu, tim audit juga mempunyai peran yang penting dalam meminimalisir kerugian negara.
\end{abstract}

Kata kunci : tarif bea masuk, barang impor, Undang - undang kepabeanan.

\section{PENDAHULUAN \\ 1.1 Latar Belakang}

Republik Indonesia sebagai
negara hukum menghendaki terwujudnya sistem hukum nasional yang mantap dan mengabdi kepada kepentingan nasional yang bersumber hukum pada Pancasila dan UndangUndang Dasar 1945. Akan tetapi, sejak kemerdekaan Undang-undang kepabeanan nasional belum dapat dibentuk sehingga Indische Tarief Wet
(Undang-Undang Tarif Indonesia) Staatsblaad Tahun 1873 Nomor 35, Rechten Ordonnantie (Ordonansi Bea) Staatsblaad Tahun 1882 Nomor 240 dan Tarief Ordonnantie (Ordonansi Tarif) Staatsblaad Tahun 1910 Nomor 628 masih diberlakukan berdasarkan Pasal II Aturan Peralihan Undang-Undang Dasar 1945.[1]

Dalam sistem kepabeanan, fungsi kepabeanan diatur dalam Undang-Undang Kepabeanan Indonesia sebagaimana dinyatakan dalam ketentuan pokok Pasal 2 ayat (1) 
Undang-Undang Kepabeanan yang menentukan bahwa barang yang dimasukkan dalam daerah pabean terutama bea masuk dan berdasarkan proposisi ketentuan pokok tersebut, status yuridis barang sejak saat pemasukan ke dalam daerah pabean sampai dengan dipenuhinya kewajiban kepabeanan menjadi objek pengawasan Pejabat Bea dan Cukai. Adapun kewenangan Pejabat Bea dan Cukai untuk melakukan pengawasan, pemeriksaan dan penegahan terhadap sarana pengangkut.[2] Kewenangan Pejabat Bea dan Cukai dalam menetapkan tarif dan nilai pabean diatur dalam Pasal 16 ayat (1) dan (2) UndangUndang Nomor 10 Tahun 1995 tentang Kepabeanan sebagaimana telah diubah dengan Undang-Undang Nomor 17 Tahun 2006.

Nilai pabean adalah nilai yang digunakan sebagai dasar menghitung Bea Masuk dan Pajak dalam Rangka Impor. Kegunaan penentuan nilai pabean bagi pihak pabean adalah untuk meneliti kebenaran nilai pabean yang diberitahukan oleh Importir. Jika pemberitahuan nilai pabean oleh importir adalah benar, maka benar pulalah penghitungan Bea Masuk dan Pajak dalam rangka impor.

Importir yang nakal cenderung untuk memanipulasi pemberitahuan nilai pabean ini dengan maksud ia dapat membayar Bea Masuk dan Pajak dalam rangka impor yang rendah. Caranya ialah dengan memalsukan dokumen pelengkap pabean berupa invoice atau mengubah uraian barang atau spesifikasi teknis barang yang tidak sesuai dengan keadaan sebenarnya.[3]

\subsection{Rumusan Masalah}

Berdasarkan latar belakang tersebut diatas maka penuis mengetengahkan dua permasalahan yaitu :

1. Bagaimana pengaturan mengenai tarif bea masuk atas barang impor berdasarkan Undang-Undang Nomor 10 Tahun 1995 tentang Kepabeanan sebagaimana telah diubah dengan Undang-Undang Nomor 17 Tahun 2006 ?

2. Bagaimana akibat hukum dari pengaturan tarif bea masuk atas barang impor berdasarkan Undang-Undang Nomor 10 Tahun 1995 tentang Kepabeanan sebagaimana telah diubah dengan Undang-Undang Nomor 17 Tahun 2006 ?

\subsection{Tujuan Penelitian}

1. Untuk mengetahui pengaturan tarif bea masuk atas barang impor berdasarkan UndangUndang Nomor 10 Tahun 1995 tentang Kepabeanan sebagaimana telah diubah dengan Undang-Undang Nomor 17 Tahun 2006.

2. Untuk mengetahui akibat hukum dari pengaturan tariff bea masuk atas barang impor berdasarkan Undang-Undang Nomor 10 Tahun 1995 tentang Kepabeanan sebagaimana telah diubah dengan UndangUndang Nomor 17 Tahun 2006.

\section{METODE PENELITIAN}

Tipe penelitian hukum yang digunakan adalah yuridis normatif. Metode penelitian yuridis normatif adalah suatu prosedur penelitian ilmiah 
untuk menemukan kebenaran berdasarkan logika keilmuan hukum dari sisi normatifnya.[4] Oleh karena tipe penelitian yang digunakan adalah tipe penelitian yuridis normatif, maka pendekatan yang digunakan adalah pendekatan perundang-undangan (statute approach) untuk memahami hierarkhi dan asas-asas dalam peraturan perundang-undangan.[5]Dengan

pendekatan perundang-undangan (statute approach), penulis ingin mengkaji kewenangan Direktorat Jenderal Bea dan Cukai sebagai salah satu institusi fiskal yang memiliki kewenangan untuk mengawasi pemasukan barang impor ke dalam daerah pabean dengan tujuan untuk memaksimalkan penerimaan negara berdasarkan Undang-Undang Nomor 10 Tahun 1995 tentang Kepabeanan sebagaimana telah diubah dengan Undang-Undang Nomor 17 Tahun 2006. Selain pendekatan perundangundangan (statute approach), digunakan pula pendekatan konsep (conceptual approach) untuk memahami konsepkonsep tentang kepabeanan, khususnya tentang tarif bea masuk atas barang impor.

\section{HASIL DAN PEMBAHASAN}

Banyak orang lebih senang menyebut dengan singkat Bea Cukai. Sebenarnya yang dimaksud adalah Direktorat Jenderal Bea dan Cukai (DJBC), atau dapat pula yang dimaksud adalah pegawai DJBC. Di forum internasional bagi institusi Bea Cukai digunakan sebutan Administrasi Pabean (Customs Administration) yang ruang lingkup tugasnya meliputi kepabeanan dan cukai atau hanya bidang kepabeanan saja.
Kalau melihat masa berlaku ketiga peraturan perundang-undangan produk Belanda yang begitu lama, timbul pertanyaan, begitu hebatkah peraturan perundang-undangan itu dalam implementasinya, dalam arti memenuhi empat aspek, yaitu dapat mencegah penyelundupan, mengoptimalkan penerimaan negara (Bea Masuk dan Pajak Dalam Rangka Impor), memberikan deterent efek yang jitu kepada pelanggar serta dapat mengakomodir semua perkembangan yang terjadi di bidang perdagangan internasional dan kepentingan ekonomi nasional.

Pengaturan tarif bea masuk ini dimulai dengan kegiatan impor. Barang-barang impor ini akan diangkut oleh sarana pengangkut dari luar/dalam daerah pabean menuju daerah pabean. Pengangkut yang sarana pengangkutnya akan datang wajib memberitahukan rencana kedatangan sarana pengangkutnya ke kantor pabean tujuan sebelum kedatangan sarana pengangkut. Sarana pengangkut ini dilengkapi dengan dokumen surat muatan, bill of lading untuk sarana pengangkut melalui laut dan airway bill untuk sarana pengangkut udara

Pengurusan pemberitahuan pabean atas barang impor dilakukan oleh pengangkut/importir. Dalam hal pengurusan pabean tidak dilakukan sendiri, importir dapat memberikan kuasanya kepada Pengusaha Pengurusan Jasa Kepabeanan (PPJK). Selain diatur dalam UU Kepabeanan, PPJK juga diatur dalam Peraturan Menteri Keuangan Nomor 65/PMK.04/2007 tanggal 20 Juni 2007 tentang Pengusaha Pengurusan Jasa Kepabeanan dan Peraturan Direktur Jenderal Bea dan Cukai Nomor P-22/BC/2007 tanggal 4 
Juli 2007 tentang Petunjuk Pelaksanaan Pemberian Nomor Pokok dan Pengawasan Pengusaha pengurusan Jasa Kepabeanan.

Terhadap barang impor dilakukan pemeriksaan pabean. Pada dasarnya pemeriksaan pabean dilakukan dalam daerah pabean, namun dengan mempertimbangkan kelancaran arus barang dan/atau pengamanan penerimaan negara, Menteri Keuangan dapat menetapkan pelaksanaan pemeriksaan pabean diluar daerah pabean oleh Pejabat Bea dan Cukai atau pihak lain yang bertindak untuk dan atas nama Direktorat Jenderal Bea dan Cukai.[6] Pemeriksaan pabean diatur dalam Pasal 3 Undang-Undang Nomor 10 Tahun 1995 tentang Kepabeanan sebagaimana telah diubah dengan Undang-Undang Nomor 17 Tahun 2006. Dalam pemeriksaan pabean juga dikenal beberapa penjaluran antara lain jalur merah, jalur hijau, jalur kuning, jalur MITA Non-Prioritas dan jalur MITA Prioritas.[7] Pemeriksaan pabean tidak hanya pemeriksaan fisik saja, melainkan juga pemeriksaan dokumen. Orang yang akan melakukan kewajiban pabean wajib melakukan registrasi ke Direktorat Jenderal Bea dan Cukai untuk mendapatkan nomor identitas dalam rangka akses kepabeanan.

Prinsip yang dianut dalam pembayaran Bea Masuk adalah asas perhitungan sendiri (self assessment). Namun, Pejabat Bea dan Cukai tetap diberi kewenangan untuk meneliti dan menetapkan tarif dan nilai pabean untuk perhitungan Bea Masuk yang tersebut dalam pemberitahuan pabean yang diserahkan importir.Penetapan tarif dan nilai pabean diberikan sebelum atau sesudah pemberitahuan pabean atas impor yang diserahkan. Importir yang salah memberitahukan nilai pabean untuk menghitung Bea Masuk sehingga mengakibatkan kekurangan pembayaran Bea Masuk dikenai sanksi administrasi berupa denda paling banyak 500\% (lima ratus persen) dari Bea Masuk yang kurang dibayar atau paling sedikit $100 \%$ (seratus persen) dari Bea Masuk yang kurang dibayar. Sanksi berupa denda ini diatur dalam Peraturan Pemerintah Nomor 28 Tahun 2008 tentang Sanksi Administrasi berupa Denda di Bidang Kepabeanan.

Penetapan klasifikasi barang dan nilai pabean oleh Direktur Jenderal Bea dan Cukai dibedakan menjadi 2 yaitu pre-entry classification dan valuation ruling. Yang dimaksud dengan pre-entry classification yaitu penetapan klasifikasi barang oleh Direktur Jenderal Bea dan Cukai terhadap importasi barang sebelum diajukan pemberitahuan pabean atas permohonan importir. Yang dimaksud dengan valuation ruling yaitu penetapan nilai pabean oleh Direktur jenderal Bea dan Cukai yang dibuat berdasarkan hasil audit kepabeanan terhadap importasi barang yang telah dan akan dilakukan oleh importir dalam jangka waktu tertentu.[8]

Bea Masuk, Cukai, denda administrasi dan pajak dalam rangka impor, dapat dibayarkan oleh wajib bayar (importir) melalui: Bank Devisa Persepsi, Kantor Pabean dan Kantor Pos (PT. Pos Indonesia). Yang harus dipersiapkan oleh wajib bayar adalah formulir Pemberitahuan Impor Barang (PIB) atau PIB tertentu kecuali atas kiriman Pabean melalui Pos, formulir Surat Setoran Bea dan Cukai (SSBC) dan Surat Setoran Pajak (SSP) kecuali jika membayar di kantor pabean dan uang pembayaran sejumlah yang 
tercantum pada PIB/PIB Tertentu atau Penetapan Pencacahan dan Pembeaan Kiriman Pos (PPKP). Di dalam pengurusan dokumen PIB, perlu diperhatikan dokumen-dokumen pendukung sebagai salah satu dasar dalam penelitian / pemeriksaan dokumen PIB antara lain: Invoice, Bill of Lading (B/L) atau Airway Bill (AWB), Packing List, Bukti Pembayaran (SSBC/BPBC), surat kuasa untuk penyelesaian oleh PPJK, Angka Pengenal Impor (API)/APIT yang masih berlaku, copy Nomor Pokok Wajib Pajak (NPWP).[9]

Fasilitas Kemudahan Impor Tujuan Ekspor (KITE) dalam Keputusan Direktur Jenderal Bea dan Cukai Nomor KEP-205/BC/2003 tentang Petunjuk Pelaksanaan Tata Laksana Kemudahan Impor Tujuan Ekspor dan Pengawasannya terakhir kali diubah dengan Peraturan Direktur Jenderal Bea dan Cukai Nomor PER-9/BC/2011 didefinisikan sebagai pemberian pembebasan dan/atau pengembalian Bea Masuk (BM) dan/atau Cukai serta PPn dan PPnBM tidak dipungut atas impor barang dan/atau bahan untuk diolah,dirakit, atau dipasang pada barang lain yang hasilnya terutama untuk tujuan ekspor.

Fasilitas Kemudahan Impor Tujuan Ekspor (KITE) yang berupa pemberian pembebasan dan atau pengembalian Bea Masuk dan atau Cukai serta Pajak Pertambahan Nilai dan Pajak Penjualan atas Barang Mewah tidak dipungut diberikan untuk memacu ekspor terutama ekspor non-migas. Dengan fasilitas ini pada pengusaha yang melakukan pengolahan terhadap barang impornya dan ditujukan untuk diekspor maka dapat mengajukan pembebasan atau pengembalian.[10]
Menurut Adrian Sutedi, fasilitas yang diberikan kepada pengguna jasa kepabeanan adalah tidak dipungut Bea Masuk, pembebasan Bea Masuk, pembebasan atau keringanan Bea Masuk dan pengembalian Bea Masuk.[11]

Menurut WCO Handbook for Commercial Fraud Investigators ada 16 (enam belas) tipe pelanggaran utama dibidang kepabeanan, yaitu sebagai berikut: penyelundupan, uraian barang yang tidak benar, pelanggaran nilai barang, pelanggaran negara asal barang, pelanggaran fasilitas keringanan bea masuk atas barang yang diolah, pelanggaran impor sementara, pelanggaran perizinan impor/ekspor, pelanggaran transit barang, pemberitahuan jumlah muatan barang yang tidak benar, pelanggaran tujuan pemakaian, pelanggaran spesifikasi barang dan perlindungan konsumen, barang melanggar hak atas kekayaan intelektual, transaksi gelap, pelanggaran pengembalian bea, usaha fiktif dan likuidasi palsu.

Dalam Peraturan Pemerintah Nomor 28 Tahun 2008 tentang Pengenaan Sanksi Administrasi Berupa Denda di Bidang Kepabeanan dijelaskan pada Pasal 2 tentang denda, Pasal 4 tentang tingkatan pelanggaran beserta dendanya, Pasal 6 tentang besarnya denda yang disebabkan oleh kekurangan pembayaran bea masuk atau bea keluar, Pasal 7 tentang besarnya denda yang disebabkan oleh penyalahgunaan fasilitas, Pasal 8 tentang sanksi administrasi berupa denda terhadap pelanggaran atas tarif akhir bea masuk yang besarnya $0 \%$, Pasal 9 tentang pelanggaran yang ditemukan berdasarkan hasil audit. 


\section{PENUTUP \\ 4.1 Simpulan}

Berdasarkan pembahasan sebelumnya, maka dapat diambil kesimpulan sebagai berikut :

1. Berdasarkan Pasal 16 UndangUndang Nomor 10 Tahun 1995 tentang Kepabeanan sebagaimana telah diubah dengan Undang-Undang Nomor 17 Tahun 2006, Pejabat Bea dan Cukai memiliki kewenangan untuk meneliti dan menetapkan tarif dan nilai pabean untuk penghitungan Bea Masuk. Hal ini sebagai pengawasan atas prinsip yang dianut dalam pembayaran Bea Masuk yaitu asas perhitungan sendiri (self assessment).

2. Informasi tentang adanya pelanggaran di kepabeanan lebih mudah dideteksi dari dokumen impor/ekspor, antara lain : Pemberitahuan Impor Barang (PIB), Pemberitahuan Ekspor Barang (PEB), Manifest, Bill of Lading (B/L)/ Airway Bill (AWB), Invoice, Packing List, data perusahaan, data kapal, data kontainer dan lainlain.

\subsection{Saran}

Adapun beberapa saran dari pembahasan sebelumnya adalah sebagai berikut:

1. Pasal 113 B Undang-Undang Nomor 10 Tahun 1995 tentang Kepabeanan sebagaimana telah diubah dengan Undang-Undang Nomor 17 Tahun 2006 yang membahas tentang sanksi administrasi bagi Pejabat Bea dan Cukai agar di perjelas maksud dalam lampiran. Sebab jika terjadi salah penafsiran dari Pasal 113 B, maka tujuan sebenarnya dari pasal tersebut tidak akan tercapai.
2. Sanksi dibidang kepabeanan baik berupa sanksi pidana maupun sanksi administrasi hendaknya dapat dijalankan sebagaimana mestinya. Tidak hanya menjadi sebuah peraturan perundang-undangan sebagai salah satu kelengkapan negara. Sebab bea masuk merupakan salah satu sumber penerimaan negara. Sudah sepatutnya Direktorat Jenderal Bea dan Cukai melakukan pengawasan terhadap lalu lintas barang yang masuk atau keluar daerah pabean.

\section{Catatan kaki :}

[1] Achmad Dimyati, "Modul Diklat Teknis Substantif Dasar Kepabeanan dan Cukai tentang Undang-Undang Pabean", Kementerian Keuangan Republik Indonesia, Badan Pendidikan dan Pelatihan Keuangan, Pusdiklat Bea dan Cukai, 2011, halaman 4-5.

[2] Adrian Sutedi, Aspek Hukum Kepabeanan, Penerbit Sinar Grafika, Cetakan Pertama, Jakarta, 2012, halaman 3-4.

[3] Ibid halaman 168-170.

[4]Johnny Ibrahim, Teori \& Metodologi Penelitian Hukum Normatif, Bayumedia Publishing, Cetakan Keenam, Malang, 2012, halaman 57.

[5] Peter Mahmud Marzuki, Penelitian Hukum, Penerbit Kencana Prenada Media Group, Cetakan Ketujuh, Jakarta, 2011, halaman 96.

[6] Achmad Dimyati. Op.Cit. halaman 14. 
[7] Situs Resmi Direktorat Jenderal Bea Cukai,

"impor",http://www.beacukai.go.id/i ndex.ikc?page=faq/impor.html, terakhir kali diakses tanggal 5 Maret 2013

[8] Achmad Dimyati. Op. Cit. halaman 49.

[9] Djauhari Ahsjar, Pedoman Transaksi Ekspor dan Impor, Penerbit Prestasi Pustakaraya, Jakarta, Cetakan Pertama, 2007, halaman 201-202.

[10] Yan Muhtadi Arba, "Fasilitas Kemudahan Impor Tujuan Ekspor (KITE)", http://unconditionalblog.blogspot. com/2011/08/fasilitas-kemudahanimpor-tujuan-ekspor.html, tanggal 22 Agustus 2011, terakhir kali diakses tanggal 21 Mei 2013.

[11] Adrian Sutedi. Op.Cit. halaman 21.

\section{DAFTAR PUSTAKA}

\section{Literatur :}

Achmad Dimyati, "Modul Diklat Teknis Substantif Dasar Kepabeanan dan Cukai tentang UndangUndang Pabean", Kementerian Keuangan Republik Indonesia, Badan Pendidikan dan Pelatihan Keuangan, Pusdiklat Bea dan Cukai, 2011

Adrian Sutedi, Aspek Hukum Kepabeanan, Penerbit Sinar Grafika, Cetakan Pertama, Jakarta, 2012
Johnny Ibrahim, Teori \& Metodologi Penelitian Hukum Normatif, Bayumedia Publishing, Cetakan Keenam, Malang, 2012

Peter Mahmud Marzuki, Penelitian Hukum, Penerbit Kencana Prenada Media Group, Cetakan Ketujuh, Jakarta, 2011

Djauhari Ahsjar, Pedoman Transaksi Ekspor dan Impor, Penerbit Prestasi Pustakaraya, Jakarta, Cetakan Pertama, 2007

\section{Internet :}

Situs Resmi Direktorat Jenderal Bea Cukai,

"impor",http://www.beacukai.g o.id/index.ikc?page=faq/impor.h $\underline{\text { tml, terakhir kali diakses tanggal }}$ 5 Maret 2013

Yan Muhtadi Arba, "Fasilitas Kemudahan Impor Tujuan Ekspor (KITE)", http://unconditionalblog.blogspo t.com/2011/08/fasilitaskemudahan-impor-tujuanekspor.html, tanggal 22 Agustus 2011, terakhir kali diakses tanggal 21 Mei 2013. 